\title{
Hepatitis B virus $X$ protein promotes liver cell pyroptosis under oxidative stress through NLRP3 inflammasome activation
}

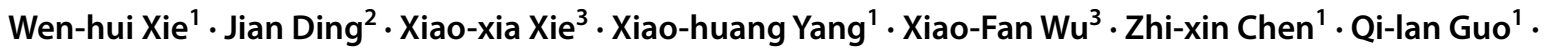 \\ Wen-yu Gao ${ }^{1} \cdot$ Xiao-zhong Wang ${ }^{1} \cdot$ Dan $^{\mathrm{Li}^{1}}{ }^{10}$
}

Received: 1 September 2019 / Revised: 11 March 2020 / Accepted: 18 April 2020 / Published online: 28 April 2020

(c) The Author(s) 2020

\begin{abstract}
Objective Hepatitis B virus X protein (HBx) is a pivotal factor for HBV-induced hepatitis. Herein, we sought to investigate HBx-mediated NLR pyrin domain containing 3 (NLRP3) inflammasome activation and pyroptosis under oxidative stress. Methods The effect of HBx on the NLRP3 inflammasome was analyzed by enzyme-linked immunosorbent assays, quantitative reverse transcription-polymerase chain reaction, western blotting, and immunofluorescence in hepatic HL7702 cells. Pyroptosis was evaluated by western blotting, lactate dehydrogenase release, propidium iodide staining, and transmission electron microscopy. NLRP3 expression in the inflammasome from liver tissues was assessed by immunohistochemistry. Results In hydrogen peroxide $\left(\mathrm{H}_{2} \mathrm{O}_{2}\right)$-stimulated $\mathrm{HL} 7702$ cells, $\mathrm{HBx}$ triggered the release of pro-inflammatory mediators apoptosis-associated speck-like protein containing a CARD (ASC), interleukin (IL)-1 $\beta$, IL-18, and high-mobility group box 1 (HMGB1); activated NLRP3; and initiated pro-inflammatory cell death (pyroptosis). HBx localized to the mitochondria, where it induced mitochondrial damage and production of mitochondrial reactive oxygen species (mitoROS). Treatment of HL7702 cells with a mitoROS scavenger attenuated HBx-induced NLRP3 activation and pyroptosis. Expression levels of NLRP3, ASC, and IL-1 $\beta$ in liver tissues from patients were positively correlated with HBV DNA concentration.

Conclusions The NLRP3 inflammasome was activated by elevated mitoROS levels and mediated HBx-induced liver inflammation and hepatocellular pyroptosis under $\mathrm{H}_{2} \mathrm{O}_{2}$-stress conditions.
\end{abstract}

Keywords Hepatitis B virus X protein · Pyroptosis $\cdot$ NLRP3 inflammasome $\cdot$ Liver inflammation

Responsible Editor: John Di Battista.

Wen-hui Xie, Jian Ding and Xiao-xia Xie contributed equally to this work.

Xiao-zhong Wang and Dan Li should be considered as joint senior authors.

Electronic supplementary material The online version of this article (https://doi.org/10.1007/s00011-020-01351-z) contains supplementary material, which is available to authorized users.

Xiao-zhong Wang

DrWangxiaozhong@163.com

Dan Li

lidan_doctor@163.com

Extended author information available on the last page of the article

\section{Introduction}

Hepatitis B virus (HBV) is an oncogenic virus presently responsible for approximately 350 million cases of chronic infections worldwide [1]. HBV's persistence is reportedly associated with an increased risk of cirrhosis and hepatocellular carcinoma (HCC) [2]. Specifically, the hepatitis viral $X$ protein $(\mathrm{HBx})$, encoded by the $H B V X$ gene, is implicated in HBV-related hepatitis, cirrhosis, and the initiation of HCC $[3,4]$. As a multifunctional oncoprotein, HBx localizes in the cytoplasm, nucleus, and mitochondria, where it affects signal transduction, transcription, and mitochondrial function $[5,6]$.

NLR pyrin domain containing 3 (NLRP3) is a cytoplasmic pattern recognition receptor that is widely distributed in hepatic parenchymal cells and non-substantial cells [7-9]. The NLRP3 inflammasome, which consists of NLRP3, inflammasome adaptor protein apoptosis-associated specklike protein containing CARD (ASC), and pro-caspase-1, 
requires two signals to be activated. The initiation signal is mediated by nuclear factor (NF)- $\mathrm{kB}$, which upregulates expression of the inflammasome-related proteins; while, the second signal is mediated by endogenous or exogenous hazard signals [10-12]. The activation of NLRP3 promotes the production of active caspase- 1 , which contains two heterodimers of $\mathrm{p} 20$ and $\mathrm{p} 10$. This activation then induces the maturation and secretion of inflammatory cytokines, namely interleukin (IL)-1 $\beta$, IL-18, and high-mobility group box 1 protein (HMGB1), as well as the induction of inflammatory necrosis (pyroptosis) [13-16]. Increasing evidence indicates that the inflammasome is involved in various liver diseases, including liver injury, hepatitis, liver fibrosis, and cirrhosis; however, whether the NLRP3 inflammasome participates in $\mathrm{HBX}$-induced hepatitis remains unclear.

The mitochondrial ROS (mitoROS) model is a widely accepted mechanistic explanation for NLRP3 activation [11, 17]. Physiological levels of ROS maintain normal cell signaling and homeostasis; however, abnormally high levels of ROS activate several signaling molecules, including NF- $\kappa B$, mitogen-activated protein kinases (MAPKs), protein kinase B (Akt), and signal transducer and activator of transcription 3 (STAT3), resulting in cellular inflammation and apoptosis [18]. Given that the mitochondrial oxidative respiratory chain serves as the primary source of intracellular ROS and that the liver is a mitochondria-rich organ, it is plausible that the mitoROS model may contribute significantly to the development and progression of liver diseases. Further, our previous studies showed that HBx interacts with cytochrome $\mathrm{c}$ oxidase subunit 3 (COXIII), a protein related to mitochondrial respiratory chains, and causes an increase in mitoROS levels, resulting in decreased membrane potential, ATP synthesis disorder, and cytosolic calcium overload, ultimately causing mitochondrial dysfunction $[19,20]$.

In the current work, we sought to investigate whether HBx promoted mitoROS-mediated liver inflammatory injury via activation of the NLRP3 inflammasome. We also examined the role of $\mathrm{HBx}$ in hepatocyte pyroptosis under oxidative stress.

\section{Materials and methods}

\section{Patient tissue and serum samples}

Archived paraffin-embedded HCC tissues and matched non-tumor tissues collected from 51 patients from 2014 to 2017 at Union Hospital of Fujian Medical University, China, were randomly selected. Written informed consent was obtained before surgical resection. Additionally, 84 serum samples, including $23 \mathrm{HBV}$-negative and $61 \mathrm{HBV}$ positive samples from patients collected between 2017 and 2018, were evaluated (tissue and serum samples were from different subjects). The inclusion criterion was patients who were first diagnosed with HBV infection and did not receive antiviral therapy. The exclusion criterion were patients with other hepatitis virus infections, nonviral hepatitis (alcoholic or non-alcoholic hepatitis, drug-induced hepatitis, etc.), and autoimmune hepatitis. All clinical samples were collected according to protocols approved by the Medical Faculty of Fujian Medical University Ethics Committee (Approval number 2019Y001).

\section{Cell culture and plasmids}

Normal human liver HL7702 cells (Shanghai Cell Biology Institute of Chinese Academy of Science, Shanghai, China) were cultured in Roswell Park Memorial Institute (RPMI) medium supplemented with $10 \%$ fetal bovine serum (Hyclone, Logan, UT, USA). For induction of oxidative stress, cells were treated with $100-\mu \mathrm{M}$ hydrogen peroxide $\left(\mathrm{H}_{2} \mathrm{O}_{2}\right)$ for $12 \mathrm{~h}$ after 36-h plasmid transfection. The other groups that were transfected with plasmids for $48 \mathrm{~h}$, however, did not undergo induced oxidative stress. The $\mathrm{pHBx}$ plasmid expressing $\mathrm{HBx}$ and pcDNA3.1 (pNC) was maintained in our laboratory. The pGEM-4Z (pGEM) plasmid was purchased from Promega (\#P2161; Madison, WI, USA). The $\mathrm{pHBV}$ plasmid expressing full-length wild-type HBV genomic complementary DNA (cDNA) and pHBV-HBxexpressing cDNA of an HBx-deficient HBV mutant were gifted from Professor M.J. Bouchard (Drexel University, Philadelphia, PA, USA) [21, 22]. Plasmid transfections were performed using Lipofectamine 3000 (\#L3000-008; Invitrogen, Carlsbad, CA, USA). $\mathrm{N}$-acetyl-L-cysteine (NAC; \#A7250; Sigma-Aldrich, St. Louis, MO, USA) was dissolved in distilled deionized water $\left(\mathrm{ddH}_{2} \mathrm{O}\right)$ and added to cells at a final concentration of $5 \mathrm{nM}$ prior to $\mathrm{H}_{2} \mathrm{O}_{2}$ treatment for 60 min. Mito-TEMPO (\#SML0737; Sigma-Aldrich, St. Louis, MO, USA) was dissolved in $\mathrm{ddH}_{2} \mathrm{O}$ and added to cells at a final concentration of $50 \mu \mathrm{M}$ before $\mathrm{H}_{2} \mathrm{O}_{2}$ treatment for $60 \mathrm{~min}$.

\section{Cell viability}

Cell viability was determined using a Cell Counting Kit-8 (CCK-8; \#CK04-11; Dojindo, Kumamoto, Japan) as described by the manufacturer. Briefly, HL7702 cells were plated into $96-$-well plates and grown to $70-80 \%$ confluence. The cells were then treated with different $\mathrm{H}_{2} \mathrm{O}_{2}$ concentrations $(0,25,50,75,100,125,150,175$, and $200 \mu \mathrm{M})$. After $12 \mathrm{~h}$ of $\mathrm{H}_{2} \mathrm{O}_{2}$ treatment, $10-\mu \mathrm{l} \mathrm{CCK}-8$ reagent was added to each well and incubated for $1 \mathrm{~h}$ at $37{ }^{\circ} \mathrm{C}$. The absorbance of each well was read at $450 \mathrm{~nm}$ using a spectrophotometric reader. 


\section{Enzyme-linked immunosorbent assay (ELISA)}

The levels of ASC, IL-1 $\beta$, IL-18, and HMGB1 in cellular medium were detected by double-antibody sandwich ELISA using Quantikine ELISA kits (R\&D Systems, Minneapolis, MN, USA) according to the manufacturer's instructions. The optical density (OD) at $450 \mathrm{~nm}$ for each well was determined using a plate reader (Bio-Rad, Hercules, CA, USA).

\section{Quantitative reverse transcription-polymerase chain reaction (qRT-PCR)}

Total RNA was extracted using TRIzol Reagent (\#15596026; Invitrogen, Carlsbad, CA, USA). Following reverse transcription, the quantitative PCR reactions were performed using SYBR Green PCR Master Mix (\#17747200; Roche, Basel, Switzerland) according to the manufacturer's protocol. The primer sequences are provided in Table 1. The data from five independent experiments were analyzed using the $2^{-\Delta \Delta C \mathrm{t}}$ method values.

\section{Western blotting}

Protein expression was evaluated by western blotting, as described previously [23]. Antibodies specific for NF- $\mathrm{KB}$ p65 (\#8242; Cell Signaling Technology, Danvers, MA, USA), NLRP3 (\#sc-66846; Santa Cruz Biotechnology, Santa Cruz, CA, USA), pro-caspase-1 (\#IMG-5028; Novus Biologicals, Littleton, CO, USA), caspase-1 (\#sc-56036;

Table 1 Primers used for RT-PCR

\begin{tabular}{|c|c|}
\hline Gene & Primer sequences \\
\hline \multirow[t]{2}{*}{ NLRP3 } & Forward 5'-GGTGGAGTGTCGGAGAAG-3' \\
\hline & Reverse 5'-CTGTCATTGTCCTGGTGTCT-3' \\
\hline \multirow[t]{2}{*}{ ASC } & Forward 5'-GCTGCTGGATGCTCTGTA-3' \\
\hline & Reverse 5'-AGGCTGGTGTGAAACTGAA-3' \\
\hline \multirow[t]{2}{*}{ Caspase-1 } & Forward 5'-GAGCAGCCAGATGGTAGAG-3' \\
\hline & Reverse 5'-CCCACAGACATTCATACAGTTTC-3' \\
\hline \multirow[t]{2}{*}{ IL- $1 \beta$} & Forward 5'-TCACCTCTCCTACTCACT-3' \\
\hline & Reverse 5'-CGGTTGCTCATCAGAATG-3' \\
\hline \multirow[t]{2}{*}{ IL-18 } & Forward 5'-GACCTTCCAGATCGCTTCCTC-3' \\
\hline & Reverse 5'-GATGCAATTGTCTTCTACTGGTTC-3' \\
\hline \multirow[t]{2}{*}{ HMGB1 } & Forward 5'-TCAAAGGAGAACATCCTGGCCTGT-3' \\
\hline & Reverse 5'-CTGCTTGTCATCTGCAGCAGTGTT-3' \\
\hline \multirow[t]{2}{*}{ GSDMD } & Forward 5'-AGACCATCTCCAAGGAACTG-3' \\
\hline & Reverse 5'-GGACAACACCAGGCACTC-3' \\
\hline \multirow[t]{2}{*}{ GAPDH } & Forward 5'-GAAGGTGAAGGTCGGAGTC-3' \\
\hline & Reverse 5'-GAAGATGGTGATGGGATTTC-3' \\
\hline
\end{tabular}

NLRP3 NLR pyrin domain containing 3, ASC apoptosis-associated speck-like protein containing a caspase recruitment domain (CARD), $H M G B 1$, high-mobility group box 1, GSDMD gasdermin D, GAPDH glyceraldehyde-3-phosphate dehydrogenase
Santa Cruz Biotechnology, Santa Cruz, CA, USA), IL-1 $\beta$ (\#ab9722; Abcam, Cambridge, MA, USA), glyceraldehyde3-phosphate dehydrogenase (GAPDH) (\#2118; Cell Signaling Technology, Danvers, MA, USA), ASC (\#ab180799; Abcam, Cambridge, MA, USA), gasdermin D (GSDMD) (\#ab210070; Abcam, Cambridge, MA, USA), HBx (\#ab39716; Abcam, Cambridge, MA, USA), hepatitis B virus core protein $(\mathrm{HBc})$ (\#MAB16989; Merck Millipore, Billerica, MA, USA), and cytochrome c oxidase subunit 4 (COXIV) (\#GB11250; Wuhan Goodbio Technology, Wuhan, China) were used.

\section{Immunofluorescence}

HL7702 cells were plated into 24-well plates and grown to $50 \%$ confluence. Following plasmid transfection and $\mathrm{H}_{2} \mathrm{O}_{2}$ induction, immunofluorescence was performed. Briefly, cells were fixed with $4 \%$ paraformaldehyde for $15 \mathrm{~min}$ and permeabilized with $0.25 \%$ Triton X-100 for $15 \mathrm{~min}$. Cells were then blocked with $10 \%$ donkey serum for $60 \mathrm{~min}$, incubated with primary antibodies overnight at $4{ }^{\circ} \mathrm{C}$, and immunostained with secondary antibodies for $60 \mathrm{~min}$ at 23-25 ${ }^{\circ} \mathrm{C}$. Primary antibodies specific for ASC (\#ab180799; Abcam, Cambridge, MA, USA) and HBx (\#ab235; Abcam, Cambridge, MA, USA) were used. The secondary donkey anti-mouse IgG (H+L), Alexa Fluor 488 (\#A-21202; Invitrogen, Carlsbad, CA, USA), donkey anti-rabbit $\operatorname{IgG}(\mathrm{H}+\mathrm{L})$, and Alexa Fluor 555 (\#A-31572; Invitrogen, Carlsbad, CA, USA) antibodies were used. Finally, cells were observed using fluorescence confocal microscopy (Zeiss FM780, Jena, Germany). Pictures were taken under $63 \times$ oil microscope and excitation light wavelengths of $405 \mathrm{~nm}, 488 \mathrm{~nm}$, and $594 \mathrm{~nm}$ were selected for layer scanning with a scanning interval of $0.35 \mathrm{um} / \mathrm{layer}$. The fluorescence excitation displayed blue, green, and red, respectively.

\section{Mitochondria isolation}

Mitochondrial proteins were isolated according to the introduction of cellular mitochondria isolation kit (\#89874; Thermo Fisher Scientific, Waltham, MA, USA). Briefly, cells with $100-\mu \mathrm{M} \mathrm{H}_{2} \mathrm{O}_{2}$ treating for $12 \mathrm{~h}$ after 36 -h plasmid transfection were firstly harvested with trypsin and homogenized with Dounce Tissue Grinder on ice. Then, the postnuclear fractions were obtained by centrifuging at $700 \times g$ for $10 \mathrm{~min}$ at $4{ }^{\circ} \mathrm{C}$. To obtain a more purified fraction of mitochondria, the post-nuclear fractions were centrifuged at $3000 \times g$ for $15 \mathrm{~min}$. Finally, the mitochondria pellet was dissociated with lysis buffer (\#C3601-4; Beyotime Biotechnology, Shanghai, China) and then subjected to western blotting analysis. 


\section{Lactate dehydrogenase (LDH) release assay}

HL7702 cells were cultured in 96-well plates at a density of 5000 cells/well. After transfection with plasmids and $\mathrm{H}_{2} \mathrm{O}_{2}$ induction, the culture medium was collected. The release of lactate dehydrogenase (LDH) was determined using an LDH Cytotoxicity Detection Kit (\#04744926001; Roche, Basel, Switzerland) according to the manufacturer's protocol. The OD at $490 \mathrm{~nm}$ for each sample was determined using a microplate reader (Bio-Rad, Hercules, CA, USA).

\section{Propidium iodide (PI) staining}

Membrane pore formation was detected by PI and Hoechst 33342 staining (\#C1056; Beyotime Biotechnology, Shanghai, China). HL7702 cells were seeded into 6-well plates, transfected with plasmids, and exposed to $\mathrm{H}_{2} \mathrm{O}_{2}$. After treatment, the cells were washed with phosphate-buffered saline (PBS) and stained with Hoechst 33342 (5 $\mu \mathrm{l})$ and PI $(5 \mu \mathrm{l})$ for $20 \mathrm{~min}$ at $37^{\circ} \mathrm{C}$. The cells were washed with PBS three times and observed using a fluorescence microscope (TE2000-U, NIKON, Tokyo, Japan). The percentage of PIpositive cells was determined in three random microscopic fields.

\section{Transmission electron microscopy (TEM)}

Cell membrane integrity and mitochondrial morphological changes were determined using TEM. Cells were collected and fixed overnight at $4{ }^{\circ} \mathrm{C}$ in $0.1-\mathrm{M}$ sodium cacodylate solution ( $\mathrm{pH} 7.3$ ) containing $2 \%$ fresh glutaraldehyde. The fixed cells were treated with $1 \%$ osmium tetroxide in $0.1-\mathrm{M}$ cacodylate solution at $4{ }^{\circ} \mathrm{C}$ for $1 \mathrm{~h}$ and then stained with $1 \%$ uranyl acetate, dehydrated with ethanol, and embedded in epoxy resin. Finally, 90-nm ultrathin sections were cut and post-stained with uranyl acetate and bismuth subnitrate. The samples were visualized by TEM (TEC-NAI 1200, FEI Italia, Milan, Italy).

\section{Measurement of mitochondrial ROS levels}

Mitochondrial levels of ROS were determined using MitoSOX ${ }^{\mathrm{TM}}$ Red (\#M36008; Molecular Probes, Eugene, OR, USA) according to the manufacture's protocol. Cells in 6-well plates were transfected and treated with or without $100 \mu \mathrm{M} \mathrm{H}_{2} \mathrm{O}_{2}$. After treatment, the culture medium was removed, and the trypsinized cells were treated with $5 \mu \mathrm{M}$ MitoSOX ${ }^{\mathrm{TM}}$ Red reagent at $37{ }^{\circ} \mathrm{C}$ for $10 \mathrm{~min}$. Cells were then washed with warm PBS thrice. Fluorescence intensity was determined using BD Accuri ${ }^{\mathrm{TM}}$ C6 Flow Cytometer (BD Biosciences, San Jose CA, USA). The FlowJo software v7.6 was used to measure the mean fluorescence intensity.

\section{Immunohistochemistry}

Immunohistochemistry was performed using Polink-2 plus Polymer HRP Detection System (\#PV9001 and PV9003; Zhongshan Golden Bridge Biotechnology, Beijing, China) according to the manufacture's protocol. Primary antibodies specific for NLRP3 (\#ab4207; Abcam, Cambridge, MA, USA), ASC (\#ab180799; Abcam, Cambridge, MA, USA), and IL-1 $\beta$ (\#ab9722; Abcam, Cambridge, MA, USA) were incubated with sections overnight at $4{ }^{\circ} \mathrm{C}$. Representative images of 10 random fields per section were obtained microscopically (DMil, Leica, Wetzlar, Germany). The mean integrated optical density (IOD) was determined using ImagePro Plus software v6.0 (Media Cybernetics, Rockville, MD, USA) to evaluate the expression levels of proteins.

\section{Statistical analysis}

Data were assessed to evaluate the normal distribution and homogeneity of variance by the Shapiro-Wilk normality test and Levene's test, respectively. Comparisons between two groups following a normal distribution and equal variance were performed using a two-tailed Student's $t$ test; whereas, one-way analysis of variance (ANOVA) with Tukey posttest was used for multiple comparisons. For a non-normal distribution or uneven variance, the Wilcoxon rank-sum and Kruskal-Wallis test with Dunnett's post hoc test were performed to compare two groups or multiple groups. Data are shown as mean values \pm standard deviation (SD). $P<0.05$ was considered statistically significant. All data were analyzed using SPSS software v13.0.1 (SPSS, Inc., Chicago, IL, USA).

\section{Results}

\section{Optimization of $\mathrm{H}_{2} \mathrm{O}_{2}$-intervention concentration and verification of recombinant plasmid expression in HL7702 cells}

To determine the optimal concentration for $\mathrm{H}_{2} \mathrm{O}_{2}$ intervention, different concentrations of $\mathrm{H}_{2} \mathrm{O}_{2}$ were applied to hepatocytes to induce oxidative stress. As indicated by decreased cell viability, cells incurred oxidative-stress-induced damage from $\mathrm{H}_{2} \mathrm{O}_{2}$ treatment for $12 \mathrm{~h}$ at a concentration of $100 \mu \mathrm{M}$ (Fig. 1a). Accordingly, this treatment was used in subsequent experiments as the moderate exposure model. To assess protein expression of transfected plasmids in HL7702 cells, western blotting was performed. The results showed that pHBx, pHBx-HBx, and pHBV successfully expressed their corresponding proteins; while, no expression was detected from the control plasmids (Fig. 1b, c). 
A

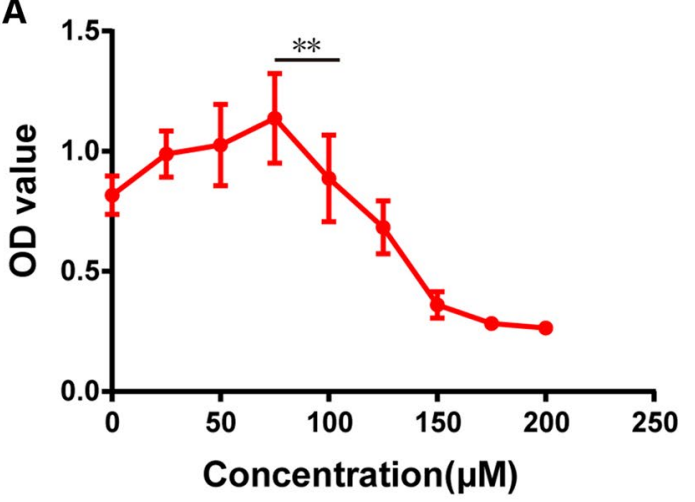

B

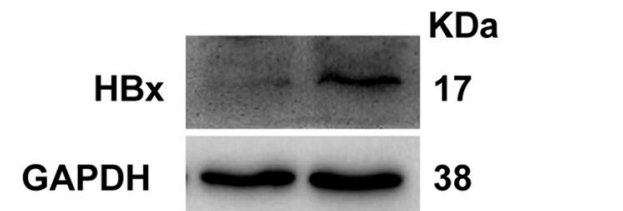

C

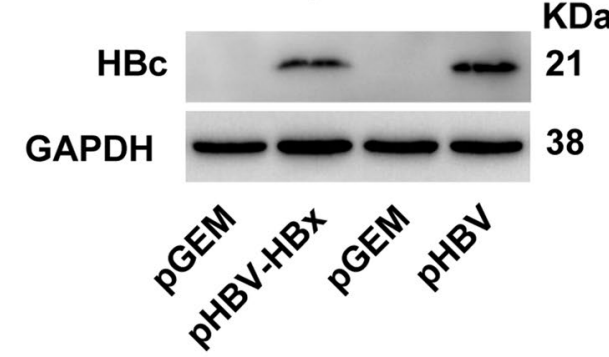

Fig. 1 Cytotoxicity of $\mathrm{H}_{2} \mathrm{O}_{2}$ and verification of recombinant plasmid expression in HL7702 cells. Cells were treated with different concentrations of $\mathrm{H}_{2} \mathrm{O}_{2}$, as indicated for $12 \mathrm{~h}$. Cell viability was evaluated using a Cell Counting Kit- 8 assay, $n=4$ (a). HBV X antigen (HBx) and $\mathrm{C}$ antigen $(\mathrm{HBc})$ were transiently expressed in HL7702 cells and protein expression levels determined by western blotting, $n=4(\mathbf{b}, \mathbf{c})$. Abbreviations: pNC, cells transfected with control vector pcDNA3.1; $\mathrm{pHBx}$, cells transfected with reconstituted $\mathrm{pHBx}$ vector; pGEM, cells transfected with control vector pGEM-4Z; pHBV-HBx, cells transfected with $\mathrm{pHBV}-\mathrm{HBx}$ vector; $\mathrm{pHBV}$, cells transfected with $\mathrm{pHBV}$ vector. Data are displayed as mean \pm SD. $* P<0.05$ and $* * P<0.01$

\section{$\mathrm{HBx}$ induces a pro-inflammatory response under $\mathrm{H}_{2} \mathrm{O}_{2}$ stimulation in hepatocytes}

Previous reports suggest that NLRP3 inflammasome-associated pro-inflammatory factor levels increase in several inflammatory liver diseases [24, 25]. To determine whether HBx promoted the secretion of inflammatory cytokines in normal liver cells, HL7702 cells were transfected with $\mathrm{HBx}$ and $\mathrm{HBV}$-expression plasmids. Under $\mathrm{H}_{2} \mathrm{O}_{2}$ stress, the release of ASC, IL-1 $\beta$, IL-18, and HMGB 1 into the culture medium increased in HBx-transfected cells (Fig. 2a). To explore whether HBV replication without $\mathrm{H}_{2} \mathrm{O}_{2}$ stressinduced similar results, HBV-expressing and control
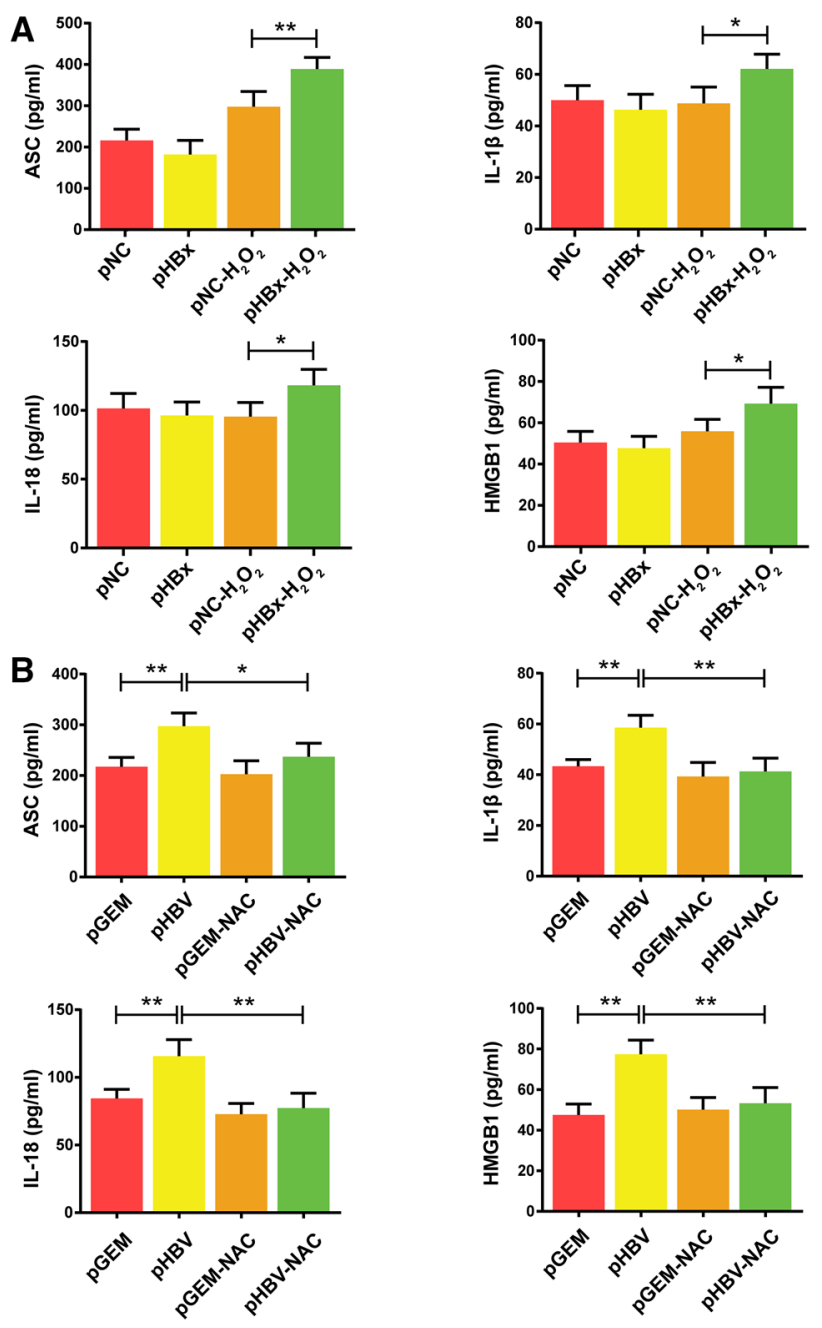

Fig. 2 Impact of hepatitis $B$ virus (HBV) $\mathrm{X}$ protein $(\mathrm{HBx})$ on the expression of inflammatory mediators in hepatocytes. Concentrations of ASC, IL-1 $\beta$, IL-18, and HMGB1 in the culture media of HBxexpressing HL7702 cells with or without $\mathrm{H}_{2} \mathrm{O}_{2}$ stimulation $(100 \mu \mathrm{M})$ were determined by ELISA, $n=4$ (a). Concentrations of ASC, IL-1 $\beta$, IL-18, and HMGB1 from HBV-expressing HL7702 cells were quantified by ELISA, $n=4$ (b). Data are presented as mean \pm SD. $* P<0.05$ and $* * P<0.01$

plasmids were transfected into HL7702 cells. Similar to that observed in the $\mathrm{HBx}$-expressing cells exposed to $\mathrm{H}_{2} \mathrm{O}_{2}$, fulllength $\mathrm{HBV}$-expression stimulated secretion of inflammatory cytokines into the cell culture medium (Fig. 2b). Collectively, these results suggest that $\mathrm{HBx}$ enhanced the release of ASC, IL-1 $\beta$, IL-18, and HMGB1 from normal hepatocytes in vitro in an oxidative stress environment.

\section{$\mathrm{HBX}$-induced NLRP3 inflammasome upregulation and activation under oxidative stress}

Since activation of the NLRP3 inflammasome promotes the transformation of pro-caspase- 1 into its active p20 and p10 
heterodimers as well as the production of mature IL-1 $\beta$, IL-18, and HMGB1, we next determined whether the oncoprotein HBx impacted the NLRP3 inflammasome in an oxidative stress microenvironment. To this end, HL7702 cells were transfected with $\mathrm{pNC}$ or $\mathrm{pHBx}$ and stimulated with $\mathrm{H}_{2} \mathrm{O}_{2}$. $\mathrm{HBx}$-expressing hepatocytes demonstrated enhanced mRNA levels of NLRP3, ASC, and caspase- 1 only in an $\mathrm{H}_{2} \mathrm{O}_{2}$-stress microenvironment (Fig. 3a). However, HBV-expression cells demonstrated elevated NLRP3, ASC, caspase-1, IL-1 $\beta$, IL-18, and HMGB1 in the absence of $\mathrm{H}_{2} \mathrm{O}_{2}$ treatment (Fig. 3b). Subsequently, protein levels of NLRP3-related molecules were detected. First, higher expression of NLRP3, Cleavedcaspase-1 (p10), ASC, IL-1 $\beta$, and NF- $\kappa$ B p65 was observed only in the $\mathrm{HBx}$ cells exposed to $\mathrm{H}_{2} \mathrm{O}_{2}$, and not in $\mathrm{HBx}$ cells without $\mathrm{H}_{2} \mathrm{O}_{2}$ intervention (Fig. 3c). Next, in an environment of $\mathrm{HBV}$ replication without $\mathrm{H}_{2} \mathrm{O}_{2}$ treatment, we determined that HBx also promoted the expression of NLRP3-related proteins in a dose-dependent manner (Fig. 3d). Furthermore, the expression of NLRP3-related proteins was similarly upregulated by HBV (Fig. 3e). Although the total pro-caspase-1 and pro-IL-1 $\beta$ protein levels did not change, the increased levels of Cleaved-caspase-1 (p10) and mature IL-1 $\beta$ suggested that the NLRP3 inflammasome was activated.

\section{HBx-induced pyroptosis in HL7702 cells treated with $\mathrm{H}_{2} \mathrm{O}_{2}$}

Since activation of the inflammasome triggered pyroptosis, we next investigated whether $\mathrm{HBx}$ would induce pyroptosis in cells exposed to oxidative stress. Pyroptosis is dependent upon active caspase-1, GSDMD, membrane pore formation, and cytolysis, resulting in leakage of $\operatorname{LDH}[9,26]$. Thus, we quantified the expression level of GSDMD, pore formation, and LDH leakage. The results revealed that $\mathrm{HBx}$ increased GSDMD expression in cells exposed to $\mathrm{H}_{2} \mathrm{O}_{2}$; whereas, cells not under $\mathrm{H}_{2} \mathrm{O}_{2}$-stimulated conditions failed to show a difference (Fig. 4a). Similarly, we observed a higher expression of GSDMD in $\mathrm{HBV}$-expressing cells without $\mathrm{H}_{2} \mathrm{O}_{2}$ stress compared with the control group (Fig. 4b). Pore formation was detected using PI staining and TEM. PI staining revealed that $\mathrm{HBx}$ significantly increased PI uptake in cells treated with $\mathrm{H}_{2} \mathrm{O}_{2}$ (Fig. 4c, d). Consistent with these findings, we also observed a higher number of PI-positive cells in HBV-expressing cell cultures (Fig. 4e, f). Moreover, TEM revealed membrane pore formation in $\mathrm{HBx}$ cells exposed to $\mathrm{H}_{2} \mathrm{O}_{2}$ and $\mathrm{HBV}$ cells without $\mathrm{H}_{2} \mathrm{O}_{2}$ treatment (Fig. $4 \mathrm{~g}, \mathrm{~h}$ ). $\mathrm{HBx}$-induced pyroptosis was further confirmed by increased LDH levels in cell culture medium (Fig. $4 \mathrm{i}-\mathrm{k}$ ).

\section{Mitochondrial ROS mediated HBx-induced NLRP3 activation and pyroptosis in liver cells}

Mitochondrial damage that causes increased intracellular ROS levels promotes inflammasome activation and pyroptosis [27]. We, therefore, investigated whether mitoROS was involved in the HBx-induced NLRP3 activation and pyroptosis upon $\mathrm{H} 2 \mathrm{O} 2$ stress. To verify the mitochondrial localization of $\mathrm{HBx}$, the mitochondrial protein was extracted and tested for $\mathrm{HBx}$. Mitochondria of $\mathrm{HBx}-$ expressing hepatocytes were found to contain HBx protein (Fig. 5a). TEM results revealed overt mitochondria swelling in HBx-expressing HL7702 cells with H2O2 treatment compared with that of the control group (Fig. 5b). Additionally, $\mathrm{H} 2 \mathrm{O} 2$-exposed HBx-expressing cells had elevated levels of mitoROS, as compared with those of H2O2-exposed cells not expressing HBx (Fig. 5c). Cells transfected with pHBVHBx or pHBV promoted increased levels of mitoROS, compared with those of the pGEM group (Fig. 5d). Also, the pHBV group had higher mitoROS levels, as compared with those of the pHBV-HBx group. Further, HBx-induced activation of the inflammasome was partially abrogated following treatment with the ROS scavenger NAC and specific mitoROS inhibitor mito-TEMPO, as suggested by the reduction of Cleaved-caspase-1 (p10) and IL-1 $\beta$ expression, PI positivity, LDH release, and inflammatory cytokine secretion (Figs. 5e-j, 2b, Supplementary Fig. 1a-b). Immunofluorescence imaging demonstrated higher expression of ASC in $\mathrm{HBx}$ cells under $\mathrm{H} 2 \mathrm{O} 2$ stress, compared with that of the control group; while, it was also apparent that $\mathrm{HBx}$ promoted the translocation of ASC from the nucleus to the cytoplasm as well as the formation of ASC specks in the cytoplasm (Fig. 5k), thereby further confirming activation of the NLRP3 inflammasome. Moreover, the translocation of ASC was partially inhibited by treating cells with the ROS scavenger NAC, and mito-TEMPO.

\section{Association between the expression level of NLRP3 inflammasome components and HBV DNA load}

To explore the clinical significance of HBV-induced changes in the expression of NLRP3 inflammasome components, a total of $51 \mathrm{HBV}$-involved HCC adjacent tissues were evaluated. Immunohistochemistry results showed that cytoplasmic levels of NLRP3, ASC, and IL-1 $\beta$ were weakly present in HBV-negative patients; however, a much stronger signal was detected in HBV-positive patients. Moreover, patients with a higher HBV DNA copy number $\left(>10^{5} \mathrm{IU} / \mathrm{ml}\right)$ had the highest cytoplasmic staining of NLRP3 (Fig. 6a-d). Correlation analysis further demonstrated that the expression level of these proteins positively correlated with HBV DNA titers (Fig. 6e-g).

Next, given that no previous research has detected the expression of serum ASC in HBV patients, we evaluated ASC concentrations in 84 serum samples from patients with or without HBV infection. In accordance with the result of ASC content in the cell culture medium (Fig. 2a-b) and cytoplasmic staining of ASC in tissues (Fig. 5a), HBV-positive 


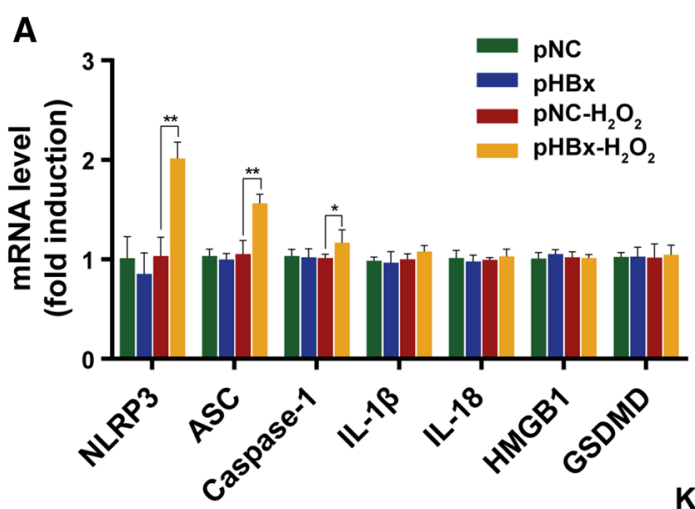

C

$$
\text { NLRP3 }
$$

pro-caspase-1

Cleaved-caspase-1 (p10)

ASC

pro-IL-1 $\beta$

$$
\begin{array}{r}
\text { IL-1 } \beta \\
\text { p65 }
\end{array}
$$

GAPDH
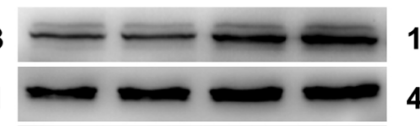

$\mathrm{KDa}$

118

45

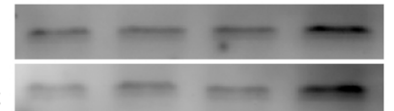

\section{0}

22

31

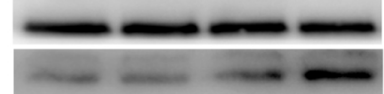

17

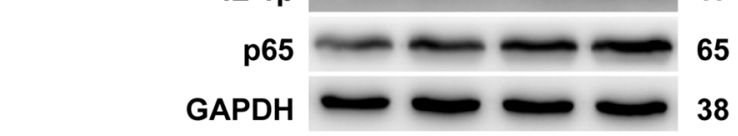

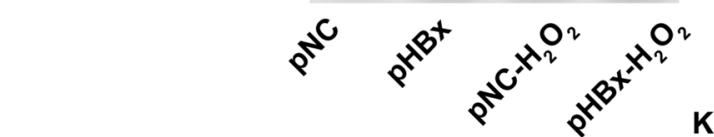

E

NLRP3 pro-caspase-1

Cleaved-caspase-1 (p10)

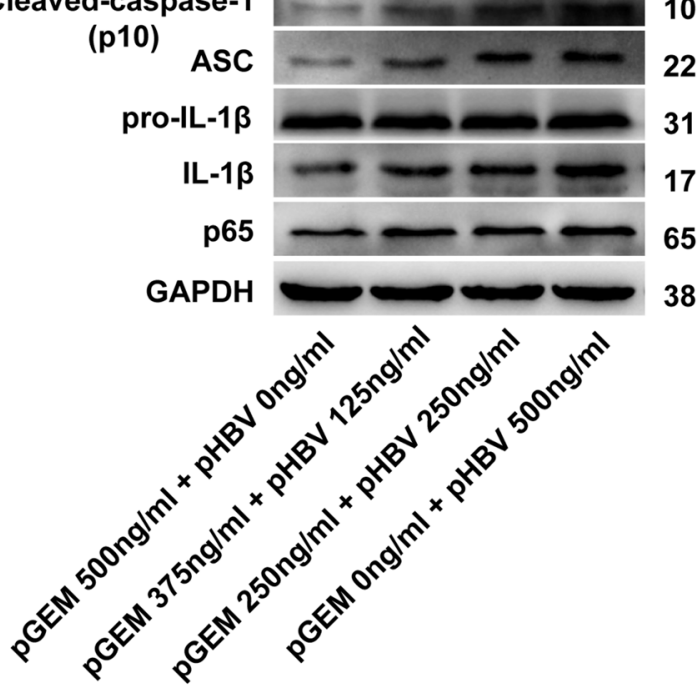

Fig. 3 HBV X protein $(\mathrm{HBx})$ promoted the upregulation and activation of NLRP3 inflammasome expression under $\mathrm{H}_{2} \mathrm{O}_{2}$ stress. Quantification of mRNA expression of GAPDH, NLRP3, ASC, caspase-1, IL-1 $\beta$, IL-18, HMGB1, and GSDMD using real-time PCR, $n=5$ (a,
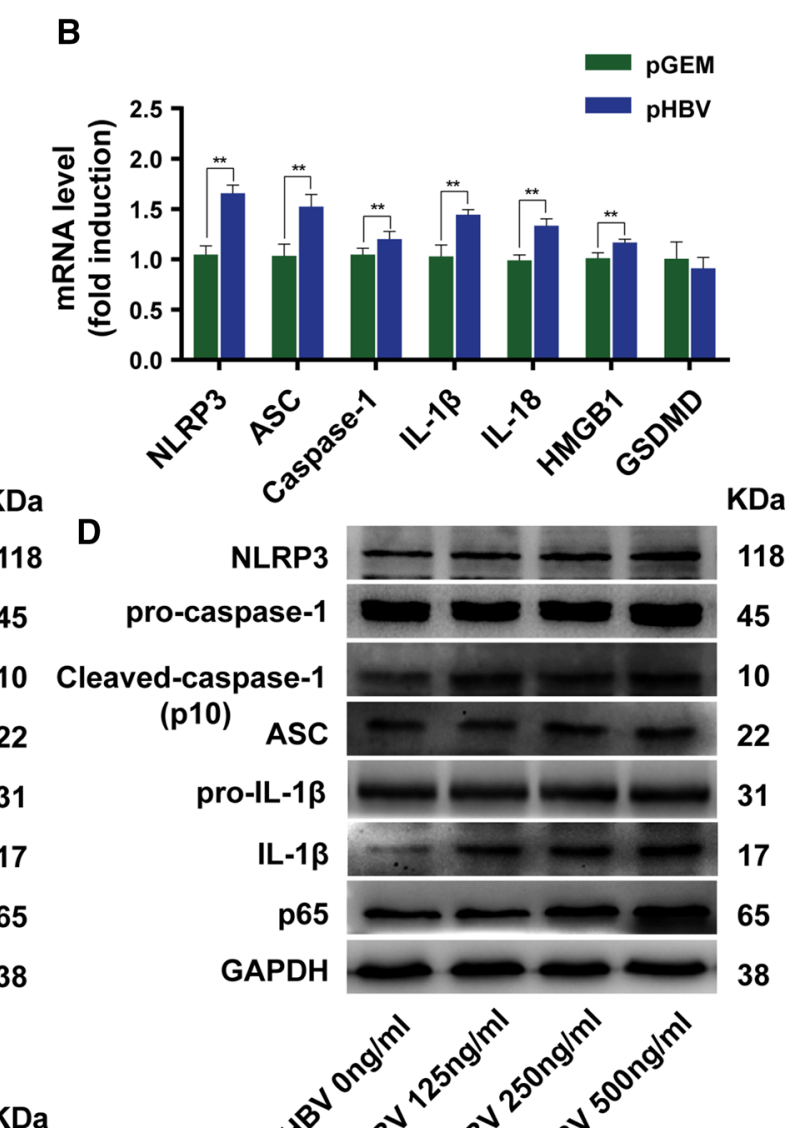

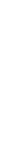

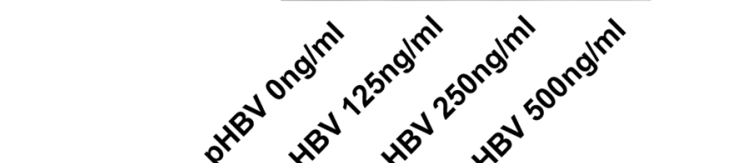


A

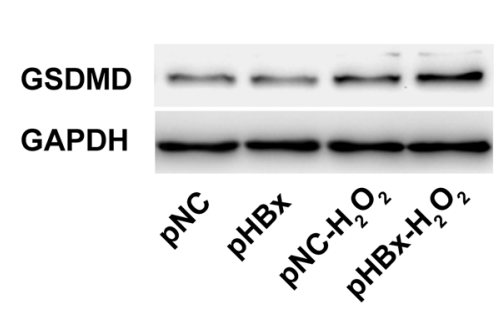

B

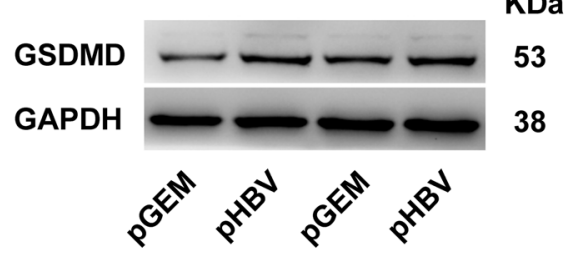

G

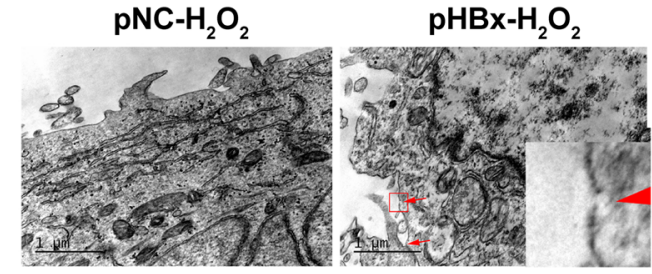

H

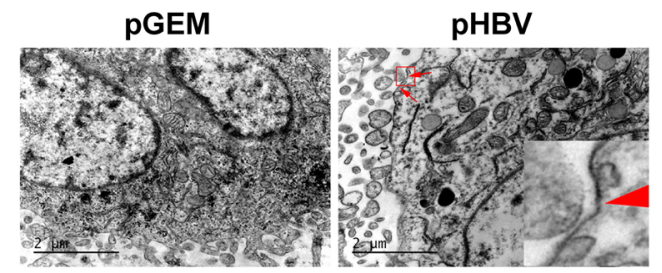

I

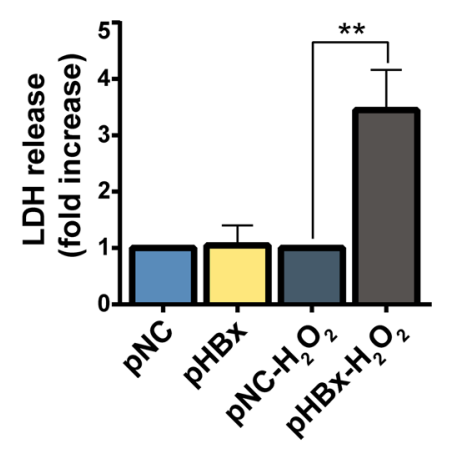

$\mathrm{KDa}$

53

38

$\mathrm{KDa}$

38

E
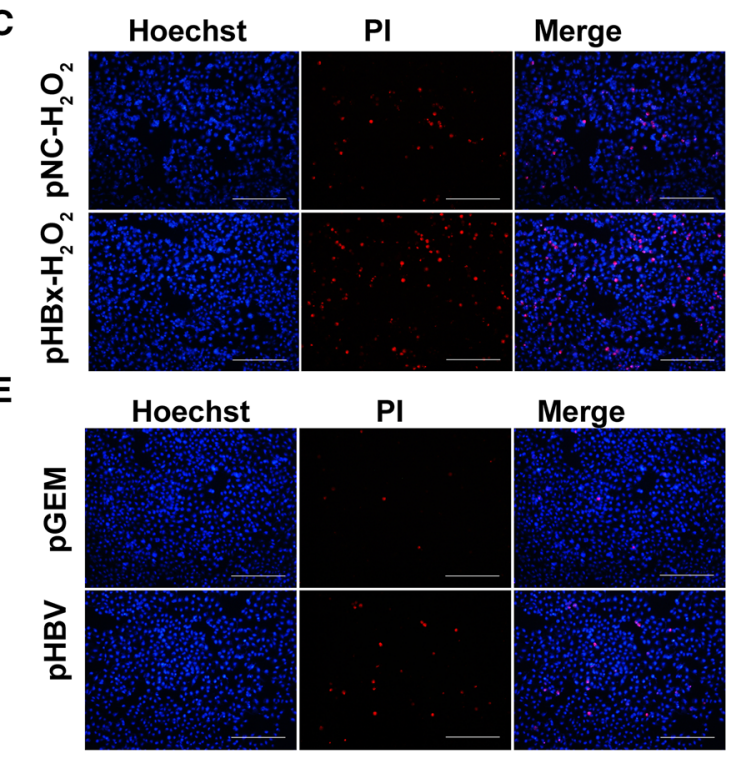

D

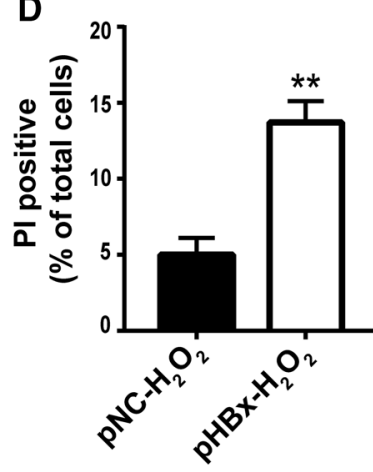

$\mathbf{F}$

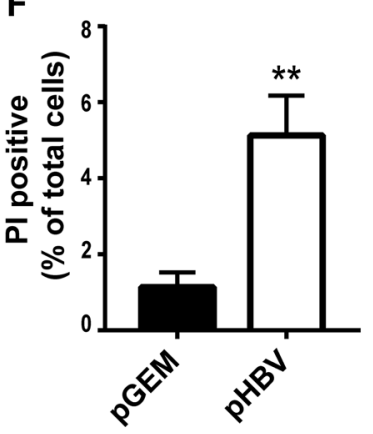

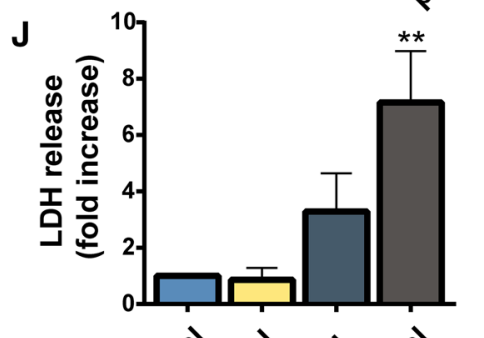
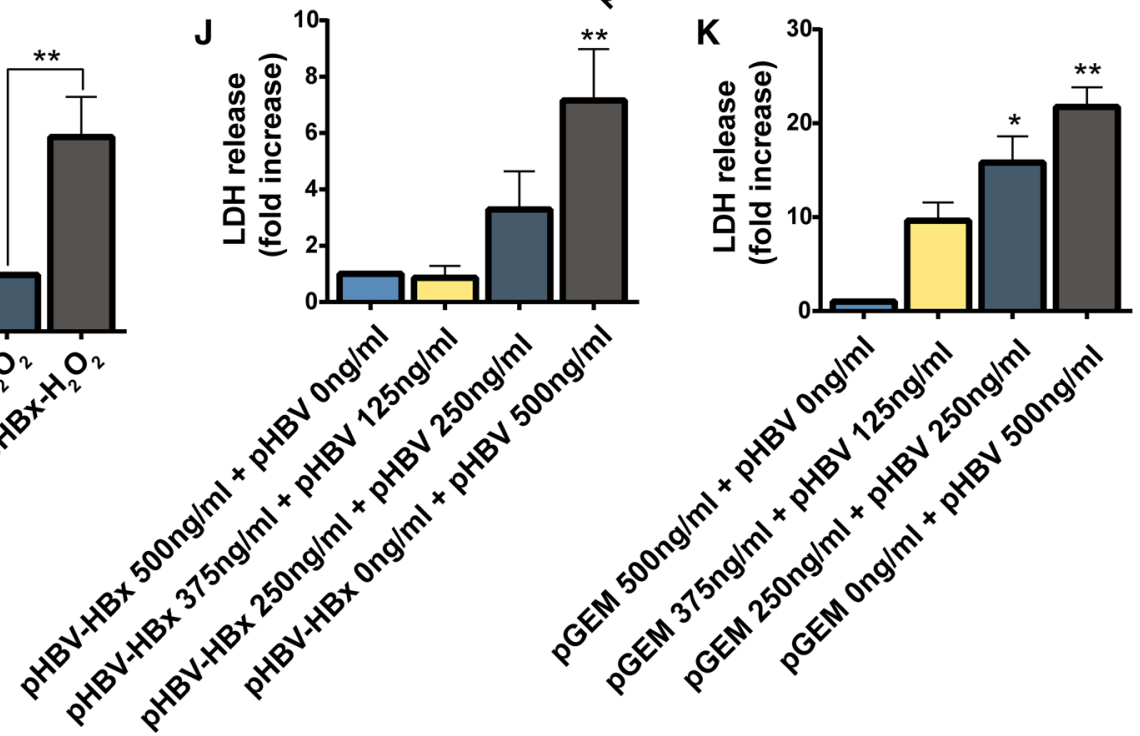

Fig. 4 Hepatitis B virus $\mathrm{X}$ protein $(\mathrm{HBx})$ induced liver cell pyroptosis under $\mathrm{H}_{2} \mathrm{O}_{2}$ stimulation. Western blot analysis of GSDMD and loading control GAPDH, $n=4(\mathbf{a}, \mathbf{b})$. Representative micrographs of PI staining (Red) and Hoechst 33342 staining (Blue), $n=5$ (c-f). Scale bar indicates $200 \mu \mathrm{m}$. The pore formation of the cellular membrane was examined by TEM, $n=4(\mathbf{g}, \mathbf{h})$. Levels of LDH released into the cell culture medium from membrane pores were examined using an LDH Cytotoxicity Detection Kit, $n=5(\mathbf{i}-\mathbf{k})$. Data are expressed as mean \pm SD. $* P<0.05$ and $* * P<0.01$ 


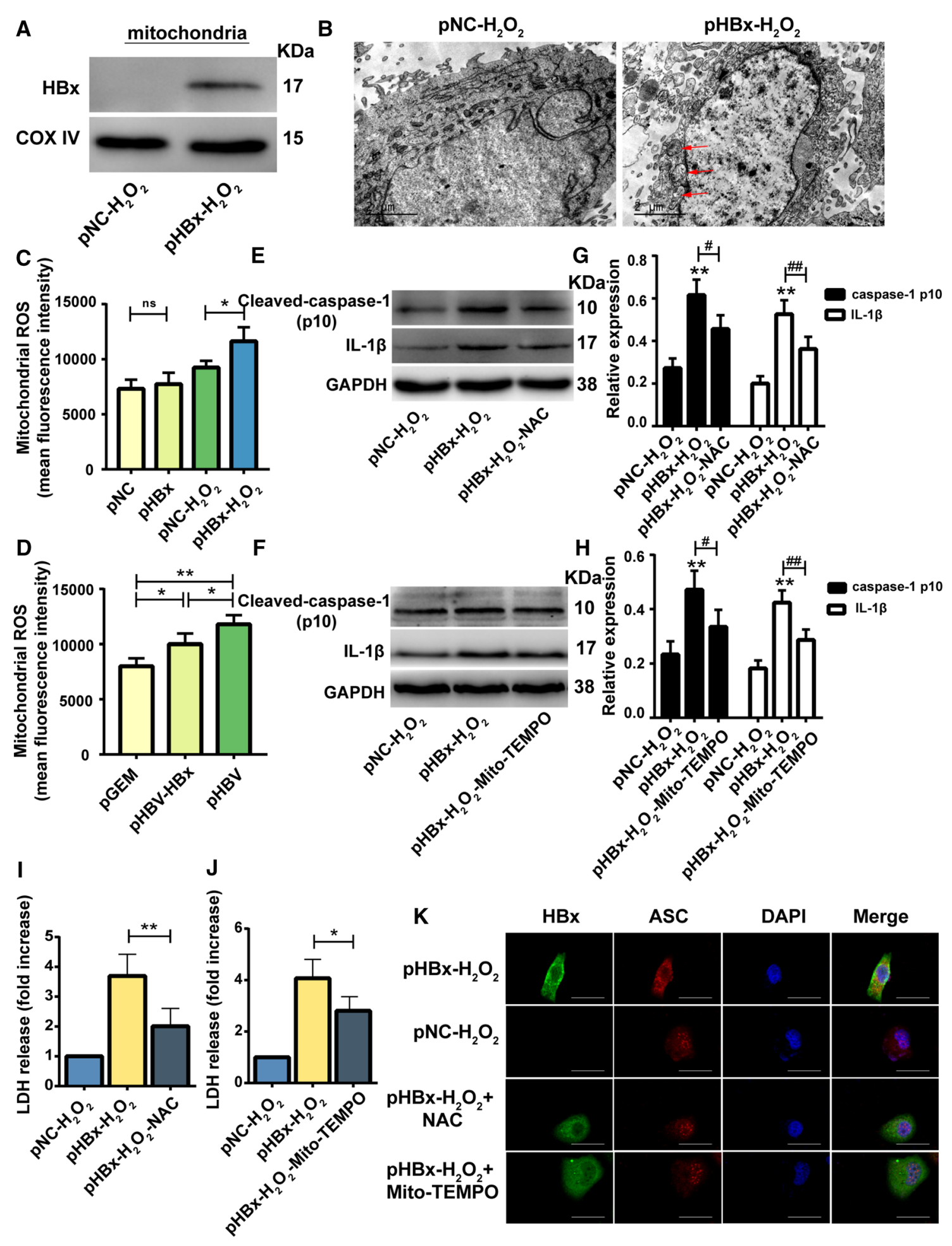

Fig. 5 Mitochondrial reactive oxygen species (mitoROS) mediated HBV X protein (HBx)-induced NLRP3 activation and pyroptosis in liver cells. Western blot analysis of HBx localized in the mitochondria. COXIV served as a loading control of mitochondrial protein, $n=4$ (a). Morphological changes of mitochondria were observed by TEM, $n=4$ (b). mitoROS levels were examined by flow cytometry, $n=4(\mathbf{c}, \mathbf{d})$. Effects of the ROS scavenger NAC and specific mitoROS inhibitor mito-TEMPO on $\mathrm{HBx}$-induced inflammasome activation analyzed by western blotting, $n=4(\mathbf{e}-\mathbf{h})$. NAC and mito-TEMPO attenuated $\mathrm{HBx}$-induced $\mathrm{LDH}$ release, $n=5(\mathbf{i}, \mathbf{j})$. NAC and mitoTEMPO inhibited both the translocation of ASC and formation of ASC specks, as detected by immunofluorescence, $n=4(\mathbf{k})$. Data are shown as mean $\pm \mathrm{SD}$. $* P<0.05, * * P<0.01, \# P<0.05, \# \# P<0.01$ 
A

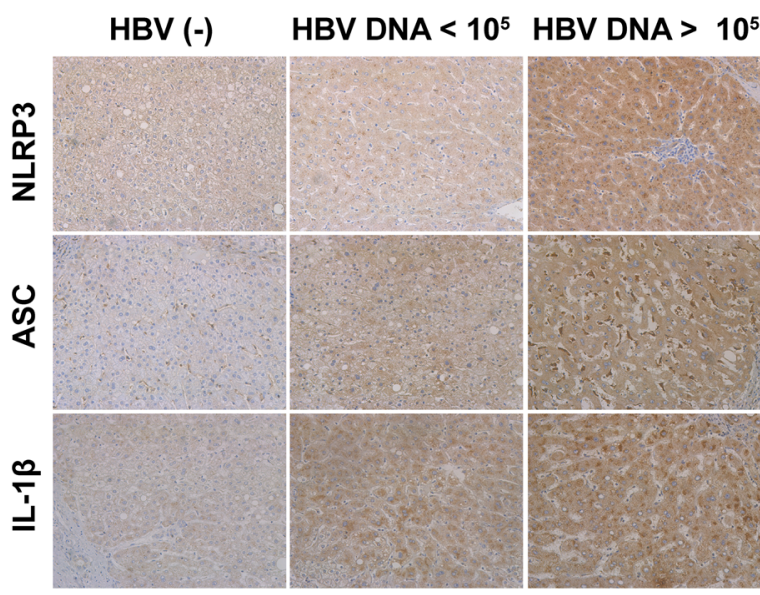

C

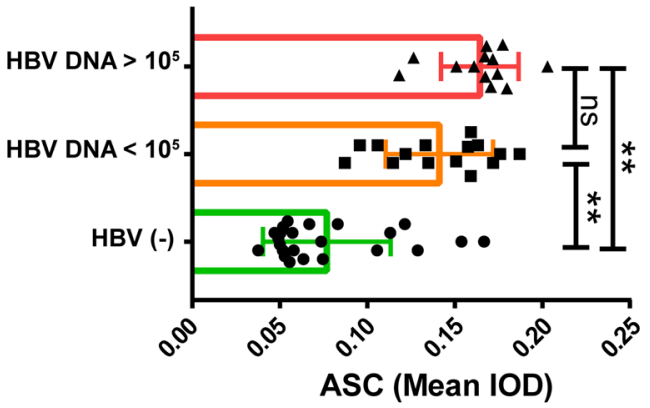

E

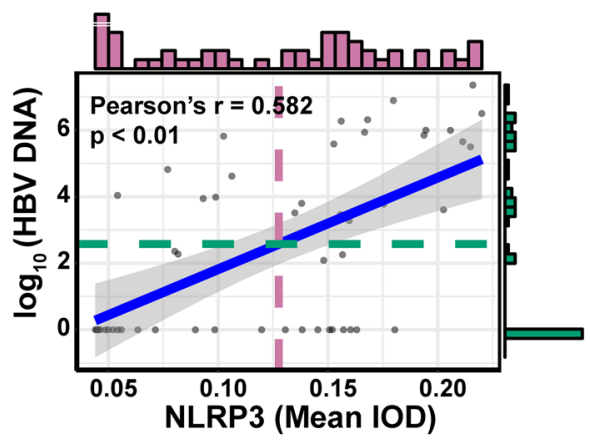

G

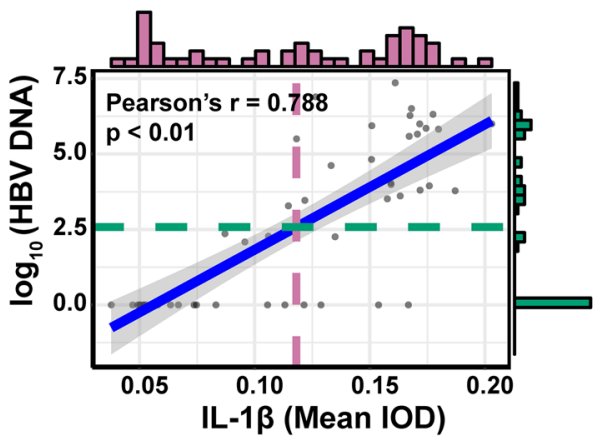

Fig. 6 Association between the expression levels of NLRP3 inflammasome components and hepatitis B virus (HBV) DNA load. Analysis by immunohistochemistry of expression levels of NLRP3, ASC, and IL- $1 \beta$ in tumor-adjacent tissues of HCC patients with or without HBV infection. Representative images are shown, and the mean integrated optical density (IOD) of protein expression was statisti-
B

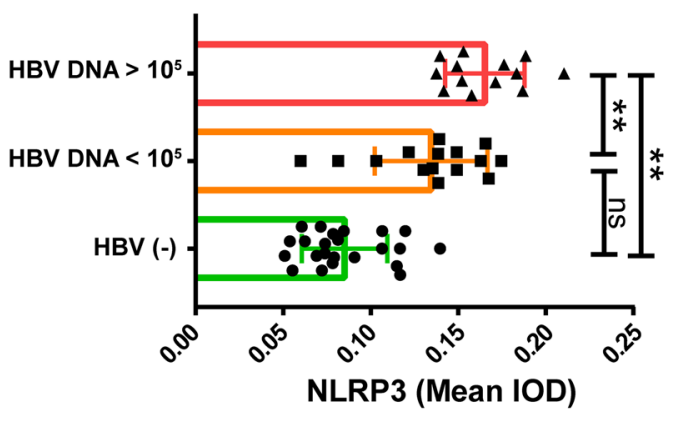

D

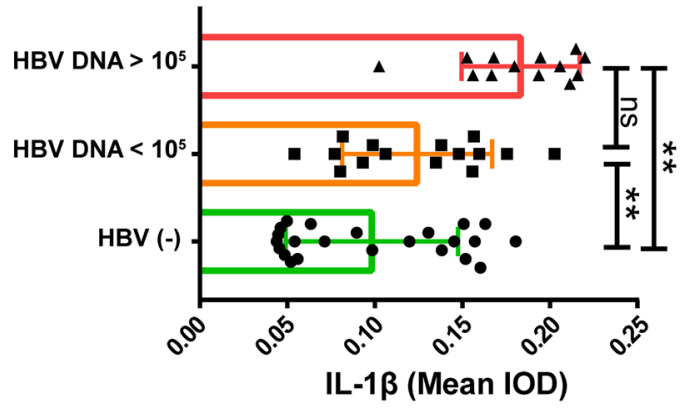

$\mathbf{F}$

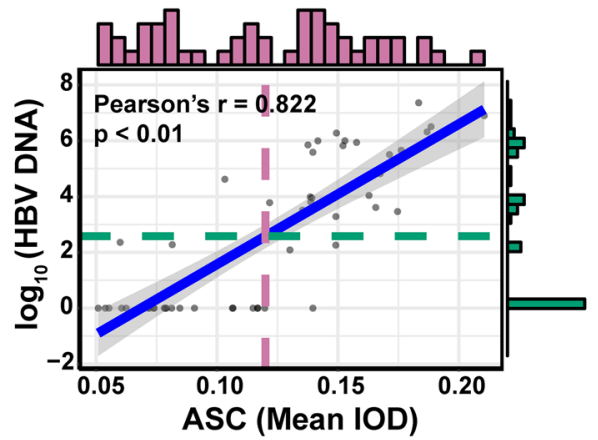

H

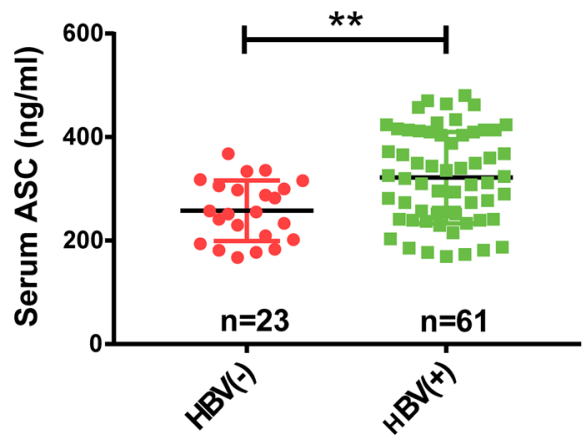

cally analyzed, $n=51$ (a-d). Pearson correlation analysis of NLRP3, ASC, and IL-1 $\beta$ expression and HBV DNA copy number in a cohort of 51 patients, $n=51(\mathbf{e}-\mathbf{g})$. Serum ASC in patients with varied HBV DNA load was detected by ELISA, $n=84$ (h). The height of the histogram represents the DNA copy number counts. Data are shown as mean \pm SD. $* P<0.05$ and $* * P<0.01$ 
patients exhibited higher ASC concentrations in their sera compared to those of HBV-negative patients (Fig. 6h). These results strongly suggest that the NLRP3 inflammasome pathway is involved in HBV-related hepatitis.

\section{Discussion}

Inflammation is the hallmark of acute and chronic liver diseases. Persistent chronic inflammation can lead to liver fibrosis, cirrhosis, and even liver cancer [28]. Among HBV proteins, $\mathrm{HBx}$ is a leading mediator of hepatic inflammation $[29,30]$. Considering that early HBV infection is primarily characterized by chronic liver inflammation, rather than employ a model of liver cancer development, we instead chose to use the standard liver cell line HL7702 to explore activation of intrahepatic cytokine networks induced by HBx. In the current study, we found that under oxidative stress, HBx enhanced NLRP3 inflammasome-mediated inflammation and pyroptosis through upregulating mitoROS production. Interestingly, in a setting of HBV replication without $\mathrm{H}_{2} \mathrm{O}_{2}$ stress, $\mathrm{HBx}$ played a similar role in mediating the NLRP3-associated inflammatory process. To the best of our knowledge, this study provides the first evidence that HBx-mediated activation of the NLRP3 inflammasome and pyroptosis required conditions, such as oxidative stress or HBV replication.

Oxidative stress is a prominent indicator of $\mathrm{HBV}$ infection. It is characterized by increased oxidative products, reduced antioxidant enzymes, and elevated ROS levels, including those of $\mathrm{H}_{2} \mathrm{O}_{2}$ [31-33]. Similarly, we found that $\mathrm{HBx}$ enhanced the levels of malondialdehyde, a product of fatty acid oxidation, and reduced the levels of the antioxidant superoxide dismutase in mice (data not shown). However, our previous studies demonstrated that HBx alone is not sufficient to induce oxidative stress [20]. Therefore, in this study, we used $\mathrm{H}_{2} \mathrm{O}_{2}$ to induce oxidative stress in cells prior to evaluating the effect of HBx on the NLRP3 inflammasome, to simulate the intrahepatic oxidative stress environment. We found that $\mathrm{HBx}$-expressing cells promoted the secretion of ASC, IL-1 $\beta$, IL-18, and HMGB1 under $\mathrm{H}_{2} \mathrm{O}_{2}$ stress. Also, HBV-expressing cells without $\mathrm{H}_{2} \mathrm{O}_{2}$ intervention also promoted the release of inflammatory cytokines. Hence, other HBV proteins may induce oxidative stress after which HBx may promote NLRP3 activation. The observed ROS levels between the pGEM and pHBV-HBx groups (Fig. 5d) confirmed this hypothesis. We also observed opposing roles for HBx on apoptosis. Similarly, Huang et al. found that HBx suppresses apoptosis of hepatoma cells during starvation by enhancing mitophagy; however, it exhibits the opposite role under well-fed conditions [23]. Taken together, these results suggest that HBx may exert specific and unique roles in different environments, while also stimulating the release of pro-inflammatory cytokines only in the presence of other specific factors, such as oxidative stress, nutrient deprivation, or the expression of other HBV proteins.

Mitochondrial injury often leads to the generation of ROS and subsequently activates the ROS signaling pathway. Rahmani et al. showed that HBx interacts with the mitochondrial human voltage-dependent anion-selective channel protein 3 (HVDAC3) and alters mitochondrial membrane potential [34]. Consistent with this, we found that HBx was present in the mitochondrial fraction isolated from $\mathrm{HBX}-$ expressing cells. TEM results demonstrated morphological changes consistent with mitochondrial damage. Moreover, exposure to $\mathrm{H}_{2} \mathrm{O}_{2}$ caused an increase in mitoROS levels in HBx-expressing cells compared to that in the control groups, indicating that $\mathrm{HBx}$ facilitated the oxidative stress-related damage. To date, the mechanism of HBx-mediated liver cell death has primarily focused on non-inflammatory cell death, such as autophagy and apoptosis [23,35]. Our current study shows, for the first time, a new form of cell death, $\mathrm{HBx}$-induced pyroptosis, in normal hepatocytes exposed to $\mathrm{H}_{2} \mathrm{O}_{2}$. Pyroptosis refers to inflammatory cell death and may play a more significant role in $\mathrm{HBV}$ infection than other types of cell death. It is generally accepted that HBx can induce the production of pro-inflammatory cytokines in various liver cells. However, the underlying mechanistic details associated with $\mathrm{HBX}$-induced inflammation remain unclear. Ample evidence suggests that NLRP3 inflammation occurs in hepatocytes, sinusoidal endothelial cells, and non-substantial cells, including Kupffer cells and hepatic stellate cells $[8,9,36]$. In comparison with that in other tissues, the expression level of caspase- 1 in the liver is higher, and Kupffer cells can produce a large amount of IL-1 $\beta$ by activating NLRP3 [37]. Based on these data, pyroptosis may be a pivotal mechanism involved in HBx-mediated inflammation, at least in HL7702 liver cells.

Contrary to the findings of $\mathrm{Yu}$ et al., which state that HBV suppresses lipopolysaccharide (LPS)-mediated NLRP3 activation [38], we found LPS-induced NLRP3 activation, primarily in Kupffer cells. One reason for this discrepancy may be differences in study aims and design. For instance, they primarily focused on the hepatitis B e antigen ( $\mathrm{HBeAg}$ ), which inhibits NLRP3 activation. Moreover, although they conducted experiments using clinical samples, the sample size was relatively small, and they did not consider the effect of HBV DNA titer on NLRP3. We demonstrated that the inflammasome expression signal was enhanced in the liver tissue of patients with increased HBV DNA copy number.

Recently, some studies have showed that ASC can be released into the extracellular space from cells via inflammasome activation and accumulate in tissue. Then, ASC is phagocytosed by the surrounding immune cells, which promotes the production of pro-inflammatory cytokines 
and spread of inflammation [39, 40]. In addition, Franklin et al. demonstrated that subcutaneous and intraperitoneal injections of ASC cause acute inflammation in mice [41]. As ASC is a newly identified inflammatory protein that can mediate the spread of inflammation, we tested the serum levels of ASC in patients with various HBV DNA loads. Interestingly, higher serum ASC levels were observed in HBVpositive patients, similar to that observed in $\mathrm{HBx}$-expressing cells. Collectively, these results suggest that HBx mediates the spread of inflammation via the promotion of ASC secretion. Further studies are needed to explore the mechanism of inflammation mediated by ASC.

Another study demonstrated that the NLRP3 inflammasome expression signal in normal, hepatitis-related, and cirrhotic tissue shows a continuously increasing trend; however, it becomes significantly reduced in hepatoma tissues [42]. Similarly, our data showed that inflammasome expression levels in liver cancer tissues from HBV-infected patients were significantly down-regulated compared with that in matched healthy para-cancer tissues (data not shown). Moreover, the mRNA and protein expression levels of the inflammasome in HepG2.2.15 cells, a human hepatoma cell line that stably expresses HBV, were decreased compared with those of control HepG2 cells (data not shown). The discrepant roles of HBV on the NLRP3 inflammasome may be dependent on the different stages of a natural HBV infection. It is possible that during the early stage of HBV infection, NLRP3 may be activated, resulting in inflammation and cell pyroptosis. Alternatively, long-lasting chronic inflammation may cause the development of liver cancer. When hepatocytes become cancerous, HBV may reduce the expression of the inflammasome and the secretion of pro-inflammatory mediators, thereby evading recognition and elimination by immune cells. Numerous studies have shown that the NLRP3 inflammasome can resist the formation of colon cancer [43], further supporting this speculation. However, the specific mechanism requires further investigation. Additionally, many studies showed that HMGB 1 is an upstream activator of the inflammasomes [44, 45]. However, some studies have suggested that HMGB1 is a downstream protein of inflammasomes. Lamkanfi et al. showed that mice with knockout caspase 1 down-regulates LPS-induced HMGB1 production compared to wild-type mice. Also, the LPSinduced release of HMGB1 from macrophages depends on the activation of the NLRP3 inflammasome [46]. Hou et al. reported that pyroptosis enhances the secretion of HMGB1 in macrophages [47]. Chen et al. demonstrated that an adipokine (visfatin) can activate the NLRP3 inflammasome in vascular endothelial cells and promote the production of HMGB1, which leads to damage to the intercellular connections in the vascular endothelium [48]. Similarly, we observed that $\mathrm{HBx}$ increases the secretion of HMGB1 in hepatocytes under $\mathrm{H}_{2} \mathrm{O}_{2}$-stimulation, whereas NAC reduces the secretion of HMGB1 via inhibition of the activation of the NLRP3 inflammasome. The inconsistencies in the above results may be related to the complexity of cell signaling pathway regulation and the different types of cells and tissues.

While important new findings are provided, limitations in the current work have been noted. For instance, only a single human normal hepatic cell line was used in this study. Evaluation of other normal hepatic cell lines is, therefore, required. Also, the current study did not include any animal studies, which may provide relevant and essential insights.

In summary, under conditions of oxidative stress, $\mathrm{HBx}$ activated NLRP3 in normal hepatocytes and promoted pyroptosis via the mitochondrial ROS pathway, ultimately causing the release of ASC, IL-1 $\beta$, IL-18, and HMGB1. Our study may provide novel insights into the mechanisms involved in HBV-induced hepatitis.

Acknowledgements This work was supported by the Fujian Natural Science Foundation (2018J01314), the Fujian Province Health and Family Planning Research Talent Training Project (2018-CX-21), the Joint Funds for the Innovation of Science and Technology, Fujian Province (2017Y9048), and the Fujian Minimally Invasive Medical Center (Health Office Medical Care Administration File of South Fujian [2017] No. 171). We gratefully thank Professor Linying Zhou (Laboratory of Electron Microscopy, Fujian Medical University) for providing technical support with transmission electron microscopy (TEM).

\section{Compliance with ethical standards}

Conflict of interest The authors declare no conflict of interest.

Open Access This article is licensed under a Creative Commons Attribution 4.0 International License, which permits use, sharing, adaptation, distribution and reproduction in any medium or format, as long as you give appropriate credit to the original author(s) and the source, provide a link to the Creative Commons licence, and indicate if changes were made. The images or other third party material in this article are included in the article's Creative Commons licence, unless indicated otherwise in a credit line to the material. If material is not included in the article's Creative Commons licence and your intended use is not permitted by statutory regulation or exceeds the permitted use, you will need to obtain permission directly from the copyright holder. To view a copy of this licence, visit http://creativecommons.org/licenses/by/4.0/.

\section{References}

1. Lavanchy D. Hepatitis B virus epidemiology, disease burden, treatment, and current and emerging prevention and control measures. J Viral Hepatitis. 2004;11(2):97-107.

2. Perz JF, Armstrong GL, Farrington LA, Hutin YJ, Bell BP. The contributions of hepatitis $B$ virus and hepatitis $C$ virus infections to cirrhosis and primary liver cancer worldwide. J Hepatol. 2006;45(4):529-38. https://doi.org/10.1016/j.jhep.2006.05.013.

3. Neuveut C, Wei Y, Buendia MA. Mechanisms of HBV-related hepatocarcinogenesis. J Hepatol. 2010;52(4):594-604. https://doi. org/10.1016/j.jhep.2009.10.033. 
4. Lee WP, Lan KH, Li CP, Chao Y, Lin HC, Lee SD. Oncogenic circuit constituted by Ser31-HBx and Akt increases risks of chronic hepatitis and hepatocellular carcinoma. Biochem Biophys Acta. 2016;1862(4):837-49. https://doi.org/10.1016/j.bbadi s.2015.12.020.

5. Tang H, Oishi N, Kaneko S, Murakami S. Molecular functions and biological roles of hepatitis $\mathrm{B}$ virus $\mathrm{x}$ protein. Cancer Sci. 2006;97(10):977-83. https://doi.org/10.111 1/j.1349-7006.2006.00299.x.

6. Waris G, Huh KW, Siddiqui A. Mitochondrially associated hepatitis B virus X protein constitutively activates transcription factors STAT-3 and NF-kappa B via oxidative stress. Mol Cell Biol. 2001;21(22):7721-30. https://doi.org/10.1128/ mcb.21.22.7721-7730.2001.

7. Csak T, Ganz M, Pespisa J, Kodys K, Dolganiuc A, Szabo G. Fatty acid and endotoxin activate inflammasomes in mouse hepatocytes that release danger signals to stimulate immune cells. Hepatology (Baltimore, MD). 2011;54(1):133-44. https://doi.org/10.1002/ hep.24341.

8. Wree A, Eguchi A, McGeough MD, Pena CA, Johnson CD, Canbay A, et al. NLRP3 inflammasome activation results in hepatocyte pyroptosis, liver inflammation, and fibrosis in mice. Hepatology (Baltimore, MD). 2014;59(3):898-910. https://doi. org/10.1002/hep.26592.

9. Watanabe A, Sohail MA, Gomes DA, Hashmi A, Nagata J, Sutterwala FS, et al. Inflammasome-mediated regulation of hepatic stellate cells. Am J Physiol Gastrointest Liver Physiol. 2009;296(6):G1248-57. https://doi.org/10.1152/ajpgi.90223 2008 .

10. Bauernfeind FG, Horvath G, Stutz A, Alnemri ES, MacDonald $\mathrm{K}$, Speert $\mathrm{D}$, et al. Cutting edge: NF-kappaB activating pattern recognition and cytokine receptors license NLRP3 inflammasome activation by regulating NLRP3 expression. J Immunol (Baltimore, Md : 1950). 2009;183(2):787-91. https://doi.org/10.4049/ jimmunol.0901363.

11. Jin C, Flavell RA. Molecular mechanism of NLRP3 inflammasome activation. J Clin Immunol. 2010;30(5):628-31. https://doi. org/10.1007/s10875-010-9440-3.

12. Lamkanfi M, Dixit VM. Mechanisms and functions of inflammasomes. Cell. 2014;157(5):1013-22. https://doi.org/10.1016/j. cell.2014.04.007.

13. Shao W, Yeretssian G, Doiron K, Hussain SN, Saleh M. The caspase-1 digestome identifies the glycolysis pathway as a target during infection and septic shock. J Biol Chem. 2007;282(50):363219. https://doi.org/10.1074/jbc.M708182200.

14. Shimada K, Crother TR, Karlin J, Dagvadorj J, Chiba N, Chen S, et al. Oxidized mitochondrial DNA activates the NLRP3 inflammasome during apoptosis. Immunity. 2012;36(3):401-14. https:// doi.org/10.1016/j.immuni.2012.01.009.

15. Liu X, Zhang Z, Ruan J, Pan Y, Magupalli VG, Wu H, et al. Inflammasome-activated gasdermin $\mathrm{D}$ causes pyroptosis by forming membrane pores. Nature. 2016;535(7610):153-8. https://doi. org/10.1038/nature 18629

16. Chen X, He WT, Hu L, Li J, Fang Y, Wang X, et al. Pyroptosis is driven by non-selective gasdermin-D pore and its morphology is different from MLKL channel-mediated necroptosis. Cell Res. 2016;26(9):1007-20. https://doi.org/10.1038/cr.2016.100.

17. Gurung P, Lukens JR, Kanneganti TD. Mitochondria: diversity in the regulation of the NLRP3 inflammasome. Trends Mol Med. 2015;21(3):193-201. https://doi.org/10.1016/j.molme d.2014.11.008

18. Ivanov AV, Valuev-Elliston VT, Tyurina DA, Ivanova ON, Kochetkov SN, Bartosch B, et al. Oxidative stress, a trigger of hepatitis $\mathrm{C}$ and $\mathrm{B}$ virus-induced liver carcinogenesis. Oncotarget. 2016;8(3):3895-932.
19. Wang XZ, Li D, Tao QM, Lin N, Chen ZX. A novel hepatitis $\mathrm{B}$ virus $\mathrm{X}$-interactive protein: cytochrome $\mathrm{C}$ oxidase III. J Gastroenterol Hepatol. 2006;21(4):711-5. https://doi.org/10.111 1/j.1440-1746.2006.04139.x.

20. Gao WY, Li D, Cai DE, Huang XY, Zheng BY, Huang YH, et al. Hepatitis B virus X protein sensitizes HL-7702 cells to oxidative stress-induced apoptosis through modulation of the mitochondrial permeability transition pore. Oncol Rep. 2017;37(1):48-56. https ://doi.org/10.3892/or.2016.5225.

21. Melegari M, Scaglioni PP, Wands JR. Cloning and characterization of a novel hepatitis $\mathrm{B}$ virus $\mathrm{x}$ binding protein that inhibits viral replication. J Virol. 1998;72(3):1737-43.

22. Scaglioni PP, Melegari M, Wands JR. Posttranscriptional regulation of hepatitis B virus replication by the precore protein. J Virol. 1997;71(1):345-53.

23. Huang XY, Li D, Chen ZX, Huang YH, Gao WY, Zheng BY, Wang XZ. Hepatitis B Virus X protein elevates Parkin-mediated mitophagy through Lon Peptidase in starvation. Exp Cell Res. 2018;368(1):75-83.

24. Alegre F, Pelegrin P, Feldstein AE. Inflammasomes in liver fibrosis. Semin Liver Dis. 2017;37(2):119-27. https://doi. org/10.1055/s-0037-1601350.

25. Wree A, Marra F. The inflammasome in liver disease. J Hepatol. 2016;65(5):1055-6. https://doi.org/10.1016/j.jhep.2016.07.002.

26. Fink SL, Bergsbaken T, Cookson BT. Anthrax lethal toxin and Salmonella elicit the common cell death pathway of caspase-1-dependent pyroptosis via distinct mechanisms. Proc Natl Acad Sci USA. 2008;105(11):4312-7. https://doi.org/10.1073/pnas.07073 70105.

27. Lu Y, Xu S, Chen H, He M, Deng Y, Cao Z, et al. CdSe/ZnS quantum dots induce hepatocyte pyroptosis and liver inflammation via NLRP3 inflammasome activation. Biomaterials. 2016;90:27-39. https://doi.org/10.1016/j.biomaterials.2016.03.003.

28. Herzer K, Sprinzl MF, Galle PR. Hepatitis viruses: live and let die. Liver Int. 2007;27(3):293-301. https://doi.org/10.111 1/j.1478-3231.2006.01422.x.

29. Cho HK, Kim SY, Yoo SK, Choi YH, Cheong J. Fatty acids increase hepatitis B virus $\mathrm{X}$ protein stabilization and $\mathrm{HBx}$-induced inflammatory gene expression. FEBS J. 2014;281(9):2228-39. https://doi.org/10.1111/febs.12776.

30. Lee MO, Choi YH, Shin EC, Kang HJ, Kim YM, Jeong SY, et al. Hepatitis B virus X protein induced expression of interleukin 18 (IL-18): a potential mechanism for liver injury caused by hepatitis B virus (HBV) infection. J Hepatol. 2002;37(3):380-6.

31. Duygu F, Karsen H, Aksoy N, Taskin A. Relationship of oxidative stress in hepatitis B infection activity with HBV DNA and fibrosis. Ann Lab Med. 2012;32(2):113-8. https://doi.org/10.3343/ alm.2012.32.2.113.

32. Bolukbas C, Bolukbas FF, Horoz M, Aslan M, Celik H, Erel O. Increased oxidative stress associated with the severity of the liver disease in various forms of hepatitis B virus infection. BMC Infect Dis. 2005;5:95. https://doi.org/10.1186/1471-2334-5-95.

33. Bhargava A, Khan S, Panwar H, Pathak N, Punde RP, Varshney $\mathrm{S}$, et al. Occult hepatitis B virus infection with low viremia induces DNA damage, apoptosis and oxidative stress in peripheral blood lymphocytes. Virus Res. 2010;153(1):143-50. https://doi. org/10.1016/j.virusres.2010.07.023.

34. Rahmani Z, Huh KW, Lasher R, Siddiqui A. Hepatitis B virus $\mathrm{X}$ protein colocalizes to mitochondria with a human voltagedependent anion channel, HVDAC3, and alters its transmembrane potential. J Virol. 2000;74(6):2840-6.

35. Hu L, Chen L, Yang G, Li L, Sun H, Chang Y, et al. HBx sensitizes cells to oxidative stress-induced apoptosis by accelerating the loss of Mcl-1 protein via caspase- 3 cascade. Mol Cancer. 2011;10:43. https://doi.org/10.1186/1476-4598-10-43. 
36. Imaeda AB, Watanabe A, Sohail MA, Mahmood S, Mohamadnejad M, Sutterwala FS, et al. Acetaminophen-induced hepatotoxicity in mice is dependent on Tlr9 and the Nalp3 inflammasome. $\mathrm{J}$ Clin Investig. 2009;119(2):305-14. https://doi.org/10.1172/jci35 958.

37. Paszkowski AS, Rau B, Mayer JM, Moller P, Beger HG. Therapeutic application of caspase 1/interleukin-1beta-converting enzyme inhibitor decreases the death rate in severe acute experimental pancreatitis. Ann Surg. 2002;235(1):68-76.

38. Yu X, Lan P, Hou X, Han Q, Lu N, Li T, et al. HBV inhibits LPSinduced NLRP3 inflammasome activation and IL-1beta production via suppressing the NF-kappaB pathway and ROS production. J Hepatol. 2017;66(4):693-702. https://doi.org/10.1016/j. jhep.2016.12.018.

39. Franklin BS, Latz E, Schmidt FI. The intra-and extracellular functions of ASC specks. Immunol Rev. 2018;281(1):74-87.

40. Kuri P, Schieber NL, Thumberger T, Wittbrodt J, Schwab Y, Leptin M. Dynamics of in vivo ASC speck formation. J Cell Biol. 2017;216(9):2891-909. https://doi.org/10.1083/jcb.201703103.

41. Franklin BS, Bossaller L, De Nardo D, Ratter JM, Stutz A, Engels G, Brenker C, Nordhoff M, Mirandola SR, Al-Amoudi A, Mangan MS. The adaptor ASC has extracellular and'prionoid'activities that propagate inflammation. Nat Immunol. 2014;15(8):727.

42. Wei Q, Mu K, Li T, Zhang Y, Yang Z, Jia X, et al. Deregulation of the NLRP3 inflammasome in hepatic parenchymal cells during liver cancer progression. Lab Investig. 2014;94(1):52-62. https:// doi.org/10.1038/labinvest.2013.126.

43. Bishayee A. The role of inflammation and liver cancer. Adv Exp Med Biol. 2014;816:401-35. https://doi. org/10.1007/978-3-0348-0837-8_16.
44. Chi W, Chen H, Li F, Zhu Y, Yin W, Zhuo Y. HMGB1 promotes the activation of NLRP3 and caspase- 8 inflammasomes via NF-kappaB pathway in acute glaucoma. J Neuroinflamm. 2015;12:137. https://doi.org/10.1186/s12974-015-0360-2.

45. Kim EJ, Park SY, Baek SE, Jang MA, Lee WS, Bae SS, et al. HMGB1 increases IL-1beta production in vascular smooth muscle cells via NLRP3 inflammasome. Front Physiol. 2018;9:313. https ://doi.org/10.3389/fphys.2018.00313.

46. Lamkanfi M, Sarkar A, Vande Walle L, Vitari AC, Amer AO, Wewers MD, et al. Inflammasome-dependent release of the alarmin HMGB1 in endotoxemia. J Immunol (Baltimore, Md : 1950). 2010;185(7):4385-92. https://doi.org/10.4049/jimmu nol.1000803.

47. Hou L, Yang Z, Wang Z, Zhang X, Zhao Y, Yang H, et al. NLRP3/ ASC-mediated alveolar macrophage pyroptosis enhances HMGB1 secretion in acute lung injury induced by cardiopulmonary bypass. Lab Investig. 2018;98(8):1052-64. https://doi.org/10.1038/s4137 4-018-0073-0.

48. Chen Y, Pitzer AL, Li X, Li PL, Wang L, Zhang Y. Instigation of endothelial Nlrp3 inflammasome by adipokine visfatin promotes inter-endothelial junction disruption: role of HMGB1. J Cell Mol Med. 2015;19(12):2715-27. https://doi.org/10.1111/jcmm.12657.

Publisher's Note Springer Nature remains neutral with regard to jurisdictional claims in published maps and institutional affiliations.

\section{Affiliations}

\section{Wen-hui Xie ${ }^{1} \cdot$ Jian Ding ${ }^{2} \cdot$ Xiao-xia Xie $^{3} \cdot$ Xiao-huang Yang $^{1} \cdot{\text { Xiao-Fan } \mathrm{Wu}^{3} \cdot \text { Zhi-xin Chen }^{1} \cdot \text { Qi-lan Guo }}^{1}$. Wen-yu Gao ${ }^{1} \cdot$ Xiao-zhong Wang ${ }^{1} \cdot$ Dan $^{1} i^{1}$ (])}

1 Department of Gastroenterology, Union Hospital of Fujian Medical University, 29, Xinquan Road, Gulou, Fuzhou 350001, Fujian, People's Republic of China

2 Department of Gastroenterology, The First Affiliated Hospital of Fujian Medical University, Fuzhou 350005, Fujian, People's Republic of China
3 Graduate School, Fujian Medical University, Fuzhou 350001, Fujian, People's Republic of China 